\title{
PERAN ORGANIZATIONAL CITIZENSHIP BEHAVIOR SEBAGAI PEMEDIASI \\ PENGARUH KEPUASAN KERJA TERHADAP KINERJA PERAWAT
}

\author{
Eni Erlina Ritonga
}

\author{
Fakultas Ekonomi UIN Maulana Malik Ibrahim Malang \\ Email: ritonga 21@yahoo.com
}

\begin{abstract}
The increasingly tight competition especially in the field of service in hospital business where everyone is tying for maintain their existence within the scope of the organization. The focus of this research was to analyze the direct and indirect influence of job satisfaction on employee performance, and the role of OCB as the mediator of job satisfaction on the performance of RSI Aisyiyah Malang employees. The approach used in this research was quantitative approach.The sample collection technique used was simple random sampling. The sample in this study amounted to 61 employees of RSI Aisyiyah Malang nurses. Data collection was using questionnaires, while data analysis was done by using path analysis. The results showed that 1) there was a direct effect of job satisfaction on employee performance of RSI Aisyiyah Malang nurses. This meant that the performance of RSI Aisyiyah nurses was better if job satisfaction felt by the nurses was better too. 2) there was indirect effect of job satisfaction on employee performance of RSI Aisyiyah Malang. 3) OCB mediated the influence of job satisfaction on employee performance of RSI Aisyiyah Malang.
\end{abstract}

Keywords: Job Satisfaction, Employee Performance, and Organizational Citizenship Behavior

\section{PENDAHULUAN}

Kompetisi yang semakin ketat utamanya dibidang pelayanan antara perusahaan satu dan yang lain dalam bisnis rumah sakit, salah satunya disebabkan banyak bermunculan rumah sakit umum, swasta, non Islam, dan rumah sakit Islam dalam pasar. Seluruhnya bersaing untuk mempertahankan eksistensi di dalam ruang lingkup yang dilakukan oleh organiasai tersebut. Rumah sakit merupakan organisasi penyedia jasa kesehatan. Bagi organisasi penyedia jasa, kualitas pelayanan adalah salah satu faktor terpenting yang mempengaruhi kepuasan pelanggan. Hal ini disebabkan karena konsumen pengguna jasa berharap mendapatkan pelayanan dengan kualitas terbaik (Zeithmal dan Bitner, 1996). Kondisi tersebut mengharuskan perusahaan menentukan langkah yang harus diambil berkaitan dengan manajemen, terutama dalam bidang sumber daya manusia (SDM). 
Perawat merupakan sumber daya penting dalam suatu organisasi dalam industri rumah sakit. Karena perawat adalah orang-orang yang berhubungan langsung dengan pelanggan atau pasien rumah sakit. Semakin baik perlakuan serta perilaku yang dilakukan perawat terhadap pasien maka semakin tinggi tingkat kepuasan pasien terhadap layanan rumah sakit. Oleh karena itu, perlu bagi pihak manajemen rumah sakit memberikan kebijakankebijakan atau memperhatikan faktor-faktor yang dapat meningkatkan kinerja para perawat. Bagi perusahaan penilaian kinerja karyawan sangat penting. Menurut Mangkunegara (2005) kinerja adalah sebagai hasil kerja orang secara kualitas dan kuantitas yang dicapai oleh seorang karyawan dalam melaksanakan tugasnya sesuai dengan tanggung jawab yang diberikan kepadanya dalam suatu kurun waktu yang ditetapkan (Mangkunegara, 2005).

Kepuasan kerja menurut Robbins dan Judge (2007) adalah sikap umum terhadap pekerjaan seseorang, yang menunjukkan perbedaan antara jumlah penghargaan yang diterima pekerja dan jumlah yangmereka yakini seharusnya mereka terima. Menurut Murty \& Srimulyani (2013) dapat dikatakan pula bahwa kepuasan kerja adalah dipenuhinya keinginan dan kebutuhannya melalui kegiatan bekerja. Mangkunegara (2005) mengungkapkan kepuasan kerja adalah perasaan individu terhadap pekerjaannya. Pekerjaan ini berupa suatu hasil penilaian mengenai seberapa jauh pekerjaannya secara keseluruhan mampu memuaskan kebutuhannya. Ketidakpuasan dan rendahnya tingkat kepuasan karyawan dapat menimbulkan gangguan dan hambatan serta ketidaklancaran suatu perusahaan juga semua proses yang ada didalamnya. Hal itu ditandai dengan adanya tingginya tingkat absensi, keterlambatan, kesenjangan, memperlambat pekerjaan bahkan sampai dengan penolakan perintah dari atasan. Sebaliknya kepuasan karyawan dalam bekerja dapat menumbuhkan suatu dorongan motivasi dan semangat kerja dalam dirinya untuk menunjukkan prestasi yang lebih baik.

Kepuasan kerja merupakan salah satu faktor yang mempengaruhi kinerja karyawan. Beberapa penelitian telah membuktikan bahwa kepuasan kerja berpengaruh terhadap perilaku individu dalam lingkup organisasi. Salah satunya yaitu penelitian oleh Artadi (2015) tentang Pengaruh Kepuasan Kerja dan Beban Kerja terhadap Kinerja Karyawan pada PT. Merapi Agung Lestari, hasil penelitian ini menunjukkan kepuasan kerja berpengaruh positif dan signifikan terhadap kinerja karyawan. Dengan 
kepuasan kerja yang tinggi, hal ini tentunya baik bagi organisasi. Karyawan yang merasa puas akan memililki dedikasi dan semangat tinggi sehingga kinerjanya akan meningkat. Namun, beberapa penelitian lain menyatakan bahwa kepuasan kerja tidak berpengaruh terhadap kinerja karyawan, seperti penelitian yang dilakukan oleh Febriana (2015), yang meneliti tentang Pengaruh Kepuasan Kerja terhadap Kinerja Karyawan PT. Kabepe Chakra 2015, hasil penelitian menunjukkan bahwa kepuasan kerja tidak berpengaruh terhadap kinerja karyawan, diprediksi ada kemungkinan terdapat faktor-faktor lain yang mempengaruhi kepuasan kerja terhadap kinerja yang tidak diteliti dalam penelitian ini.

Dari beberapa penelitian diatas terdapat kontradiksi antara hasil penelitian satu dengan penelitian lainnya, sehingga peneliti ingin mengkaji kembali tentang bagaimana pengaruh Kepuasan Kerja terhadap Kinerja Karyawan.

Dalam organisasi biasanya setiap anggota bekerja sesuai job description, namun akan lebih baik jika mereka bisa bekerja lebih dari sekedar tanggung jawab pekerjaannya. Hal inilah yang disebut dengan Organizational Citizenship Behavior (OCB). Organ (1988) mendefinisikan OCB sebagai perilaku yang merupakan pilihan inisiatif individual, tidak berkaitan dengan sistem reward formal organisasi tetapi secara agrerat meningkatkan efektifitas organisasi. Menurut Batson (1988) OCB adalah perilaku membantu orang lain, terlepas dari motif si penolong. Tindakan prososial mulai dari tindakan alturisme tanpa pamrih sampai tindakan yang dimotivasi oleh pamrih atau kepentingan pribadi. Robbins dan Judge (2007) fakta menunjukkan bahwa organisasi yang mempunyai karyawan dengan OCB yang baik akan memiliki kinerja yang lebih baik dari organisasi lain, hal ini dikarenakan bahwa karyawan yang memiliki OCB tinggi akan dapat mengendalikan perilakunya sendiri sehingga dapat memilih perilaku yang terbaik untuk kepentingan organisasinya.

Kemudian posisi kepuasan kerja dalam membentuk perilaku OCB dan kinerja karyawan juga sangat penting karena kepuasan kerja memiliki beberapa aspek yang menunjukkan kepuasan kerja yang tinggi, yaitu: merasa puas terhadap pekerjaan itu sendiri, kepuasan terhadap gaji yang diterima, memiliki hubungan yang baik dengan atasan, memiliki hubungan baik dengan rekan kerja, dan memiliki keinginan untuk berkesempatan promosi. Pihak manajemen harus mempersiapkan suasana yang tepat untuk 
meningkatkan kepuasan kerja di tempat kerja jika ingin melibatkan karyawan berperilaku OCB. Orang-orang yang memiliki tingkat kepuasan kerja yang tinggi akan terpicu untuk melakukan perilaku-perilaku baik diluar job description.

Perilaku OCB dalam Islam dikenal dengan perilaku amal shaleh dengan keikhlasan. Kerja yang ikhlas dan berperilaku citizenship dengan mengharapkan ridha dari Allah SWT sebagaimana diperintahkan dalam surah Al- An'am: 162. Adapun ciri pekerja ikhlas menurut Farid (dalam Nurdiana, 2011) adalah memiliki kapasitas hati yang besar, memiliki kejernihan pandangan, selalu memberi lebih. Seorang pekerja ikhlas selalu berupaya untuk memberikan lebih dari yang diminta darinya. Mereka tidak akan ragu melakukan pekerjaan tambahan yang melampaui deskripsi kerjanya. Mereka juga mau membantu rekan kerja, memudahkan pekerjaannya bahkan membantu berbagai persoalan yang dimilikinya, serta menjadikan harta, tahta, kata dan cinta menjadi sumber manfaat bagi orang lain.

\section{KAJIAN PUSTAKA}

\section{Kepuasan Kerja}

Kepuasan kerja merupakan sesuatu yang bersifat individu, setiap individu memiliki tingkat kepuasan kerja yang berbeda, sesuai dengan sistem nilai-nilai yang berlaku pada diri individu itu sendiri, hal ini disebabkan oleh adanya perbedaan pada dirinya dan masing-masing individu. Seorang yang puas lebih menyukai pekerjaannya daripada karyawan yang tidak puas. Menurut Luthans (1998) dalam Wulandari (2015), kepuasan kerja merupakan keadaan emosi seseorang yang secara positif maupun menyenangkan dihasilkan dalam suatu pekerjaan atau pengalaman kerja. Robbins (2003) dalam Artadi (2015), mengatakan bahwa kepuasan kerja merupakan sikap umum terhadap pekerjaan seseorang, yang menunjukkan perbedaan antara jumlah penghargaan yang diterima pekerja dengan jumlah yang seharusnya mereka terima.

\section{Indikator Kepuasan Kerja}

Indikator untuk mengukur kepuasan kerja menurut Robbins dan Judge (2007) :

a. Kepuasan terhadap Gaji 
Gaji merupakan upah yang diperoleh seseorang dibandingkan dengan upaya yang telah dilakukan, dan besarnya upah yang diterima sama dengan upah yang diterima orang lain dalam posisi yang sama.

b. Kepuasan terhadap Pekerjaan Itu Sendiri

Sejauhmana pekerjaan mampu membangkitkan rasa senang dan menyediakan kesempatan untuk belajar memperoleh tanggung jawab dalam suatu tugas tertentu dan tantangan untuk pekerjaan yang menarik.

c. Kepuasan terhadap Sikap Atasan

Sejauhmana perhatian bantuan teknis dan dorongan ditunjukkan oleh atasan terhadap bawahan. Atasan yang memiliki hubungan personal yang baik dengan bawahan serta mampu memahami kepentingan bawahan, dan partisipasi bawahan dalam pengambilan keputusan memberikan dampak positif terhadap kepuasan pegawai.

d. Kepuasan terhadap Rekan Kerja

Tingkat dimana rekan kerja pandai secara teknis dan mendukung secara sosial. Bagi kebanyakan pegawai, kerja merupakan salah satu cara untuk memenuhi kebutuhan interaksi sosial. Sehingga rekan kerja yang menyenangkan mampu meningkatkan kepuasan kerja.

e. Kepuasan terhadap Promosi

Mengacu pada sejauh mana perusahaan memberikan kesempatan maju kepada setiap pegawainya, memberikan kesempatan untuk berada diantara jenjang berbeda dalam organisasi. Keinginan untuk promosi mencakup keinginan untuk pendapatan yang lebih tinggi, status sosial, pertumbuhan secara psikologis dan keinginan untuk rasa keadilan.

\section{Kinerja}

Kinerja berasal dari pengertian performance. Ada pula yang yang memberikan pengertian performance sebagai hasil kerja atau prestasi kerja. Kinerja mempunyai makna yang lebih luas, bukan hanya hasil kerja, tetapi termasuk bagaimana proses pekerjaan berlangsung. Mathis dan Jackson (2004) mengatakan bahwa kinerja (performance) adalah apa yang dilakukan atau tidak dilakukan oleh karyawan.

Menurut Kaswan (2012) kinerja karyawan adalah yang mempengaruhi seberapa banyak atau besar mereka memberi kontribusi organisasi. Selanjutnya Kaswan mengatakan bahwa untuk mendefinisikan kinerja dengan akurat, seorang manajer atau pimpinan harus 
memperhatikan 3 unsur, yaitu goal (sasaran), measures (ukuran), dan assessment (penilaian). Sedangkan Mangkunegara (2005) mendefinisikan kinerja karyawan (prestasi kerja) adalah hasil kerja secara kualitas dan kuantitas yang dicapai oleh seorang karyawan dalam melaksanakan tugasnya sesuai tanggung jawab yang diberikan kepadanya.

Dari beberapa definisi di atas, maka kinerja yang dimaksud dalam penelitian ini adalah hasil kerja (output) baik kualitas maupun kuantitas yang dicapai persatuan periode waktu dalam melaksanakan tugas kerjanya sesuai dengan tanggung jawab yang diberikan dan sesuai dengan standar kerja yang ada. Jadi kinerja dalam konsep ini adalah kuantitas dan kualitas pekerjaan yang diselesaikan oleh karyawan.

\section{Indikator Kinerja}

Menurut Bernardin dan Russel (1993), ada enam kriteria utama sebagai indikator yang digunakan untuk menilai kinerja, diantaranya adalah sebagai berikut: Kualitas: tingkat sejauhmana proses atau penyesuaian pada cara yang ideal di dalam melakukan aktifitas atau memenuhi aktifitas yang sesuai harapan; Kuantitas: jumlah yang dihasilkan diwujudkan melalui nilai mata uang, jumlah unit, atau jumlah dari siklus aktifitas yang telah diselesaikan; Ketepatan waktu: sejauhmana aktifitas telah diselesaikan dengan waktu yang lebih cepat dari yang ditentukan dan memaksimalkan waktu yang ada untuk aktifitas itu; Efektivitas biaya: sejauhmana penggunaan sumber daya perusahaan berupa manusia, keuangan, dan teknologi dimaksimalkan untuk mendapatkan hasil yang tertinggi atau pengurangan kerugian dari tiap unit; Kebutuhan untuk supervisi yaitu kondisi dimana seseorang karyawan dapat melakukan pekerjaannya tanpa perlu meminta pertolongan atau bimbingan dari atasannya; Dampak interpersonal yaitu kondisi dimana seorang karyawan merasa percaya diri, punya keinginan yang baik, dan bekerja sama di antara rekan kerja.

\section{Organizational Citizenship Behavior (OCB)}

Organ (1988) mendefinisikan Organizational Citizenship Behavior (OCB) merupakan perilaku individu yang bebas, tidak berkaitan secara langsung dengan sistem imbalan serta dapat meningkatkan fungsi efektif organisasi. Definisi OCB sebagai berikut : (a) Perilaku suka rela, bukan merupakan tindakan yang terpaksa terhadap hal-hal yang mengedepankan kepentingan organisasi; (b) Perilaku individu sebagai wujud dari kepuasan berdasarkan kinerja, tidak diperintahkan secara formal; (c) Tidak berkaitan 
secara langsung dan terang-terangan dengan sistem reward formal (Fitriastuti, 2013).

Organ (1988) berpendapat bahwa perilaku citizenship atau ekstra peran ini di implementasikan dalam 5 bentuk perilaku, yaitu:

a. Altruism (perilaku membantu orang lain). Sifat mementingkan kepentingan orang lain, seperti memberikan pertolongan pada kawan sekerja yang baru, dan menyediakan waktu untuk orang lain. Dimensi ini mengarah kepada memberi pertolongan yang bukan merupakan kewajiban yang ditanggungnya.

b. Conscientiousness (ketelitian dan kehati-hatian atau kedisiplinan). Sifat kehati-hatian seperti efisiensi menggunakan waktu, dan tingkat kehadiran tinggi. Perilaku ini berusaha untuk melebihi yang diharapkan oleh perusahaan atau perilaku yang suka rela yang bukan merupakan kewajiban atau tugas karyawan.

c. Sportsmanship (perilaku yang sportif). Sifat sportif dan positif, seperti menghindari komplain dan keluhan. Sportsmanship adalah dengan memaksimalkan total jumlah waktu yang dipergunakan pada usahausaha yang konstruktif dalam organisasi. Perilaku yang memberikan toleransi terhadap keadaan yang kurang ideal dalam organisasi tanpa mengajukan keberatan- keberatan. Seseorang yang mempunyai tingkatan yang tinggi dalam sportsmanship akan menunjukkan sikap yang positif dan menghindar untuk melakukan komplain. Sportsmanship akan meningkatkan iklim yang positif diantara karyawan, karyawan akan lebih sopan dan bekerja sama dengan yang lain, sehingga akan menciptakan lingkungan kerja yang lebih menyenangkan.

d. Courtesy (menjaga hubungan baik). Menjaga hubungan baik dengan rekan sekerjanya agar terhindar dari masalah-masalah interpersonal. Seseorang yang memiliki dimensi ini adalah orang yang menghargai dan memperhatikan orang lain, seperti: sifat sopan dan taat terhadap rekan kerja maupun kepada atasan sekalipun. Courtesy dapat membantu mencegah timbulnya masalah dan memaksimalkan penggunaan waktu.

e. Civic virtue (kebijaksanaan warga). Perilaku yang mengindikasikan tanggung njawab pada kehidupan organisasi, seperti mengikuti perubahan dalam organisasi, mengambil inisiatif untuk merekomendasikan bagaimana operasi atau prosedur-prosedur organisasi dapat diperbaiki, dan melindungi sumber-sumber yang 
dimiliki oleh organisasi. Dimensi ini mengarah kepada tanggung jawab yang diberikan organisasi kepada seseorang untuk meningkatkan kualitas bidang pekerjaan yang ditekuninya. Sifat bijaksanan atau keanggotaan yang baik, seperti melayani komite atau panitia, melakukan fungsi-fungsi sekalipun tidak diwajibkan untuk membantu memberikan kesan baik bagi organisasi. Civic virtue dapat memberikan pelayanan yang diperlukan bagi kepentingan organisasi.

Menurut Nurdiana (2012), perilaku citizenship (OCB) ini dikenal dengan perilaku amal shaleh dengan keikhlasan. Perilaku citizenship identik dengan perilaku ikhlas yang dilakukan tanpa mengharap imbalan atau reward dari pimpinan, tetapi semata-mata karena kesadaran dari hati yang mengedepankan kecintaan dan membantu sesama.

Nurdiana (2012) menyatakan bahwa dimensi OCB dalam perspektif Islam adalah sebagai berikut :

a. Al-truisme (Taawun)

Seorang muslim agar selalu membantu saudaranya yang lain. Allah menjanjikan bahwa orang yang suka membantu orang lain, maka akan dibantu dan diberi kemudahan oleh Allah SWT. Muslim meriwayatkan hadits sebagai berikut:

"Setiap muslim itu bersedekah, jika tidak mampu maka berbuat sesuatu dengan tangannya dan bermanfaat untuknya dan mensedekahkannya, jika tidak mampu maka membantu orang yang membutuhkan dan yang kesusahan, jika tidak mampu maka berbuat baik, jika tidak mampu maka mencegah kejelekan, semua itu termasuk sedekah" (HR. Muslim).

Hadits tersebut memberi pengertian bahwa sedekah bukan hanya berupa harta, tetapi membantu rekan kerja menyelesaikan tugas termasuk sedekah, Tirmidzi juga meriwayatkan bahwa menghilangkan batu atau duri dapat diartikan sebagai membantu orang lain atau menghilangkan kendala yang dihadapi adalah termasuk sedekah.

b. Sportif

Sportif diartikan sebagai kemauan untuk mempertahankan sikap positif ketika sesuatu tidak sesuai, tidak sakit hati ketika orang lain tidak mengikuti sarannya, mau mengorbankan kepentingan pribadi demi organisasi dan tidak menolak ide orang lain. Oleh sebab itu al- Quran menganjurkan untuk saling menasihati satu sama lain, sebagai upaya mengingatkan jika terjadi kesalahan atau kealpaan sebagai manusia. 
"Rasulullah bersabda: Aku diutus untuk menegakkan sholat, mengeluarkan zakat dan saling menasihati sesama saudara sesama muslim" (HR.Bukhori: 55).

Hadits tersebut mengajarkan perbuatan saling menasihati dengan perintah sholat dan zakat. Begitu pentingnya perilaku ini, sehingga Jarir bin Abdillah mempunyai komitmen besar kepada nabi untuk melaksanakan sholat, mengeluarkan zakat dan menasihati kepada setiap muslim. Menasihati dalam hadits tersebut dapat diartikan memberikan masukan demi kebaikan orang lain ataupun organisasi. Nabi juga menyarankan agar dalam bermasyarakat saling mempermudah, saling memberi masukan, mengajari sesuatu yang belum diketahui, dan tidak marah atau emosi ketika orang lain tidak sesuai dengan apa yang diharapkan. Ini dapat dipahami bahwa dalam berorganisasi, seseorang tidak boleh mengedepankan emosinya dalam bergaul atau berperilaku, tetapi harus positif, saling menghargai dan memberikan jalan buat orang lain.

c. Courtesy (persaudaraan)

Seorang muslim hendaknya mencintai saudaranya seperti mencintai dirinya sendiri, sehingga selalu menghindari adanya permasalahan sesama teman. Bukhori meriwayatkan sebuah hadits sebagai berikut:

"Nabi bersabda : Tidak dikatakan beriman orang yang tidak mencintai orang lain sebagaimana ia mencintai dirinya sendiri". (HR.Bukhori:12)

Dari Hadits tersebut dapat dipahami bahwa jika kita mencintai orang lain seperti mencintai diri sendiri, maka tentu tidak akan saling menyakiti dan saling iri hati dan dengki, tetapi akan selalu menjaga sikap yang baik.

d. Civic virtue (Peduli)

Setiap muslim harus peduli orang lain dan juga mendatangi setiap ada undangan pertemuan ilmiah atau rapat. Ini sebagai bentuk kecintaan terhadap organisasi. Bukhori meriwayatkan hadits sebagai berikut:

"Nabi memerintahkan 7 hal dan juga melarang 7 hal, yaitu sambang orang sakit, merawat jinazah, mendoakan orang yang besin, menjawab salam, menolong orang yang teraniaya, memenuhi undangan, menepati janji". (HR. Bukhori).

Dari hadits tersebut dapat diambil sebuah kesimpulan bahwa empati atau peduli orang lain merupakan karakter seorang muslim, mulai dari hal terkecil seperti mendoakan orang yang bersin, sampai pada hal besar seperti memenuhiundangan apapun dan oleh siapapun baik mahasiswa, masyarakat 
khususnya pertemuan-pertemuan penting organisasi, juga seperti menepati janji yang hal ini dapat kita artikan dengan disiplin waktu.

e. Conscientiousnes (mujahadah)

Seorang muslim harus bersungguh-sungguh, jeli, teliti, hati-hati berlomba-lomba dalam kebaikan tanpa pamrih sedikit pun. Muslim meriwayatkan sebagai berikut:

"Rasulullah bersabda: Sesungguhnya setiap perbuatan tergantung pada keteguhan niatnya, barang siapa yang hijrah karena Allah dan Rasulnya maka hijrahnya adalah Allah dan Rasulnya, barang siapa yang hijrahnya karena dunia atau wanita yang ingin dinikahinya, maka hijrahnya tergantung pada niatnya". (HR. Muslim)

Hadits tersebut mengandung pengertian bahwa dalam melakukan segala perbuatan maka harus dilandasi oleh niat yang teguh, sehingga dalam implementasinya akan dilaksanakan dengan sungguh-sungguh, walaupun dengan pengorbanan waktu, tenaga dan harta. Karena yang demikian tersebut dipandang sebagai perbuatan yang lebih mulia dari jihad.

Dari dimensi menurut Nurdiana (2012) diatas sesuai dengan pendapat Organ. Yang membedakan hanya dari istilah dalam keislamannya serta perilaku-perilaku yang dimaksudkan oleh Organ sesuai dengan perilaku-perilaku OCB yang diperintahkan dalam Islam. Untuk itu, peneliti tertarik untuk menjadikan dimensi OCB dalam perspektif Islam ini sebagai indikator OCB dalam penelitian ini.

\section{Hubungan Kepuasan Kerja terhadap Kinerja Karyawan}

Kinerja menurut Mangkunegara (2005) adalah hasil kerja orang secara kualitas dan kuantitas yang dicapai oleh seorang karyawan dalam melaksanakan tugasnya sesuai dengan tanggung jawab yang diberikan kepadanya dalam kurun waktu ditetapkan. Hal ini berarti kinerja karyawan ialah ukuran yang dapat dijadikan aspek penilaian produktifitas dari seorang karyawan.

Kinerja dalam menjalankan fungsinya tidak berdiri sendiri tapi berhubungan dengan kepuasan kerja (Mangkunegara, 2005). Karyawan yang merasa puas akan lebih mungkin terlibat dalam organisasi yang dapat meningkatkan produktivitas, sedangkan karyawan yang tidak merasa puas akan mempengaruhi aktivitas organisasi dalam mencapai tujuan. Menurut Mathis dan Jackson (2004) meskipun kepuasan kerja itu menarik dan 
penting, hal yang paling mendasar adalah pengaruh kepuasan kerja terhadap organisasi yang akan mempengaruhi kinerja karyawan.

Dengan demikian dapat disimpulkan bahwa pengaruh kepuasan kerja terhadap kinerja adalah tinggi rendahnya tingkat kepuasan kerja karyawan yang dirasakan akan mempengaruhi kinerja karyawan. Apabila kepuasan kerja tercapai maka yang akan terjadi ialah kinerja karyawan atas organisasi tinggi.

\section{Hubungan Kepuasan Kerja terhadap OCB}

Organ pada tahun 1983 melakukan penelitian yang hasilnya menunjukkan bahwa yang mempengaruhi OCB adalah kepuasan kerja. Sampai pada tahun 1990-an, para peneliti masih menitikberatkan pada kepuasan kerja sebagai leading predictor dari OCB (Organ \& Ryan, 1995 dalam Nurdiana, 2011). Selain itu, Jahangir, Akbar, \& Haq (2004) juga mengatakan bahwa kepuasan kerja memiliki hubungan positif dengan kinerja dan $\mathrm{OCB}$, individu dengan kepuasan kerja yang tinggi memiliki kemungkinan untuk berperilaku OCB. Demikian pula dijelaskan oleh Sloat (1999) bahwa karyawan cenderung melakukan tindakan yang melampaui tanggungjawab kerja mereka apabila mereka merasa puas dengan pekerjaannya, menerima perlakuan sportif dan penuh perhatian dari para pengawas, dan percaya mereka diperlukan oleh organisasi. Dengan demikian dari penjelasan tersebut dapat dikatakan bahwa tingginya tingkat kepuasan kerja karyawan akan meningkatkan OCB karyawan tersebut.

\section{Hubungan OCB terhadap Kinerja Karyawan}

Organ (1998) OCB sebagai perilaku yang merupakan pilihan inisiatif individual atau karyawan yang tidak berkaitan dengan reward formal organisasi tetapi secara agregat dapat meningkatkan efektivitas organisasi. OCB adalah perilaku karyawan/pegawai yang melebihi tugas yang telah ditetapkan. Efektifitas suatu organisasi dapat dilihat dari hasil kerja pada tingkat individual, kelompok, dan sistem-sistem organisasi dan juga karyawan yang memiliki OCB. Fakta menunjukkan bahwa organisasi yang memnpunyai karyawan yang memiliki OCB yang baik, akan memiliki kinerja yang lebih baik dari organisasi lain (Robbins dan Judge, 2007).

\section{Hipotesis Penelitian}

Berdasarakan tujuan penelitian yang hendak dicapai dan untuk tujuan analisis dari model konsep diatas, dapat disampaikan bahwa hipotesis yang digunakan dalam penelitian ini adalah: 
P1 : kepuasan kerja berpengaruh secara langsung terhadap kinerja karyawan RSI Aisyiyah Malang.

P2 : kepuasan kerja berpengaruh secara tidak langsung terhadap kinerja karyawan RSI Aisyiyah Malang.

P3 : OCB memediasi pengaruh kepuasan kerja terhadap kinerja karyawan RSI Aisyiyah Malang.

\section{METODE}

Penelitian ini menggunakan metode pendekatan kuantitatif dengan jenis explanatory research. Penelitian dilakukan di RSI Aisyiyah Malang yang berlokasi di Jl. Sulawesi No.16 Malang. Populasi dalam penelitian ini adalah seluruh perawat RSI Aisyiyah Malang sejumlah 159 perawat. Untuk menentukan jumlah sampeldigunakan Rumus Slovin dengan presisi $10 \%$ dan diperoleh sampel sebanyak 61 responden. Teknik pengambilan sampel yang digunakan adalah simple random sampling, Sedangkan untuk mengukur pendapat dari beberapa sampel tersebut menggunakan skala likert.

Metode pengumpulan data yang digunakan dalam penelitian ini adalah kuesioner dan dokumentasi. Dalam penelitian ini terdapat 3 (tiga) variabel yang terdiri dari 1 variabel bebas: Kepuasan Kerja (X), variabel terikat: Kinerja Karyawan (Y), variabel mediasi: Organizational Citizenship Behavior (Z).

Analisis data dilakukan dengan menggunakan analisis jalur (path analysis). Bertujuan untuk mengetahui pengaruh langsung maupun tidak langsung variabel bebas (eksogen) terhadap variabel (endogen) (Sani dan Maharani, 2013).

Pengujian mediasi bertujuan mendeteksi kedudukan variabel dalam model. Pengujian hipotesis mediasi dapat dilakukan dengan prosedur yang dikembangkan oleh Sobel (1982) yang dikenal dengan Uji Sobel (Sobel Test). Uji Sobel menggunakan software Free Statistic Calculation for Sobel Test versi 4.0 .

Selanjutnya untuk menentukan sifat hubungan antara variabel baik sebagai variabel mediasi sempurna (complete mediation) atau mediasi parsial (partial mediation), atau bukan sebagai variabel mediasi, digunakan metode pemeriksaan. Metode pemeriksaan dilakukan dengan pendekatan perbedaan antara nilai koefisien dan signifikansi : (1) memeriksa pengaruh langsung variabel eksogen terhadap endogen pada model dengan melibatkan 
variabel mediasi; (2) memeriksa pengaruh langsung variabel eksogen terhadap endogen tanpa melibatkan variabel mediasi; (3) memeriksa pengaruh variabel eksogen terhadap variabel mediasi; (4) memeriksa pengaruh variabel mediasi terhadap variabel endogen (Maharani, 2017).

\section{HASIL}

Hasil analisis jalur dijelaskan dalam gambar diagram jalur dibawah ini:

ß: 0,277

Sig: 0,031

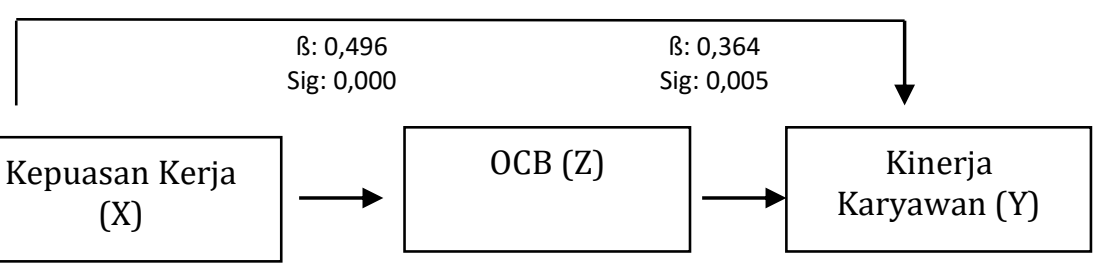

Sumber: Data Primer 2017

\section{PEMBAHASAN}

\section{Pengaruh Langsung Kepuasan Kerja terhadap Kinerja Karyawan}

Berdasarkan hasil pengujian analisis jalur, menunjukkan bahwa variabel Kepuasan Kerja mempunyai pengaruh yang signifikan terhadap variabel Kinerja Karyawan $(p=0,000>0,05)$. Maka hipotesis pertama diterima. Sehingga Kepuasan Kerja berpengaruh terhadap Kinerja Karyawan.

\section{Pengaruh Tidak Langsung Kepuasan Kerja terhadap Kinerja Karyawan Melalui OCB}

Berdasarkan hasil pengujian analisis jalur, menunjukkan bahwa kepuasan kerja mempunyai pengaruh yang signifikan terhadap OCB $(\mathrm{p}=$ $0,000<0,05$ ), selanjutnya hasil analisis jalur OCB juga mempunyai pengaruh yang signifikan terhadap kinerja karyawan $(p=0,005<0,05)$. Maka hipotesis kedua diterima. Dengan demikian dapat disimpulkan bahwa pengaruh tidak langsung kepuasan kerja terhadap kinerja karyawan melalui OCB terpenuhi. Artinya, apabila kepuasan kerja semakin tinggi diikuti dengan OCB yang semakin tinggi maka kinerja karyawan akan semakin meningkat. 


\section{OCB Memediasi Pengaruh Kepuasan Kerja terhadap Kinerja Karyawan}

Hasil pengujian sobel test mendapatkan nilai Z sebesar 2,958 >1,96 dengan tingkat signifikansi 5\%, maka dapat disimpulkan bahwa OCB mampu memediasi pengaruh kepuasan kerja terhadap kinerja karyawan pada perawat RSI Aisyiyah Malang.

Dari uji perbandingan, diperoleh hasil pada model pengaruh langsung kepuasan kerja terhadap kinerja karyawan melalui OCB mendapatkan hasil yang signifikan, begitu juga pada model pengaruh langsung kepuasan kerja terhadap kinerja karyawan tanpa melalui OCB mendapatkan hasil yang signifikan pula. Selanjutnya, dari uji perbandingan koefisien, nilai koefisien a lebih kecil dari nilai koefisien b atau $(0,277<$ 0,458). Hal ini menunjukkan nilai koefisien pengaruh tidak langsung kepuasan kerja terhadap kinerja karyawan melalui OCB lebih kecil dari nilai koefisien pengaruh langsung kepuasan kerja terhadap kinerja karyawan tanpa melibatkan OCB. Dari hasil perbandingan nilai koefisien dan signifikansi tersebut dapat disimpulkan bahwa kedudukan mediasi dalam penelitian ini ialah sebagai variabel mediasi parsial.

\section{KESIMPULAN}

Pengujian hipotesis pertama diterima, artinya terdapat pengaruh secara langsung Kepuasan Kerja terhadap Kinerja Karyawan. Pengujian hipotesis kedua diterima. Artinya terdapat pengaruh secara tidak langsung Kepuasan Kerja terhadap Kinerja Karyawan melalui OCB. Pengujian hipotesis ketiga diterima. Artinya OCB mampu memediasi Kepuasan Kerja terhadap Kinerja perawat RSI Aisyiyah Malang. Kedudukan variabel OCB sebagai variabel mediasi parsial.

\section{DAFTAR PUSTAKA}

Artadi, Febri Furqon. 2015. Pengaruh Kepuasan Kerja dan Beban Kerja terhadap Kinerja karyawan pada PT. Merapi Agung Lestari. Skripsi. Fakultas Ekonomi Universitas Negeri, Yogyakarta.

Bernardin and Russel, 1993. Human Resource Management. New Jersey: International Editions Upper Saddle River, Prentice Hall. Diterjemahkan oleh Bambang. 2006. Manajemen Sumber Daya Manusia. Edisi 10 Jakarta: Salemba Empat. 
Fitriastuti, Triana. 2013. Pengaruh Kecerdasan Emosional, Komitmen Organisasional dan Organizational Citizenship Behavior terhadap Kinerja Karyawan. Jurnal Dinamika Manajemen. Vol. 4, No. 2, 2013. pp: 103-114. Kalimantan Timur: Fakultas Ekonomi-Universitas Mulawarman Kalimantan Timur. http://journal.unnes.ac.id/ nju/index.php/jdm.

Kaswan. 2012. Manajemen Sumberdaya Manusia untuk keunggulan bersaing organisasi. Yogyakarta: Graha Ilmu.

Luthans, Fred. 2005. Organzational Behavior 10th Edition. The McGraw-Hill Companies Inc. Diterjemahkan oleh Vivin Andika Yuwono, Shekar Purwanti, Th. Arie Prabawati, dan Winong Rosari. 2006. Perilaku Organisasi Edisi 10. Yogyakarta: Andi.

Mangkunegara, Anwar Prabowo. 2005. Manajemen Sumber Daya Manusia Perusahaan. Bandung : PT Remaja Rosdakarya.

Ekowati, Maharani Vivin. 2017. Pengaruh Kepemimpinan Transformasional Terhadap OCB Dimediasi Oleh Kepuasan Kerja dan Komitmen Organisasional. Disertasi. PPSUB.

Mathis, Robert L. dan Jackson, John H.. 2004. Human Resource management. 10th Edition. Natorp Boulevard: South Western. Diterjemahkan oleh Angelica Diana. 2006. Manajemen Sumberdaya Manusia. Edisi 10. Jakarta: Salemba Empat.

Murty, Harry, \& Srimulyani, Veronika Agustini. 2013. Pengaruh Motivasi Terhadap Kinerja Pegawai Dengan Variabel Pemediasi Kepuasan Kerja Pada PDAM Kota Madiun. Jurnal Riset Manajemen dan Akutansi, 1(1), 10-17.

Nur Diana, Ilfi. 2011. Kepemimpinan Islami, Organizational Citizenship Behavior (OCB), dan Pengaruhnya terhadap Kinerja Karyawan di Universitas Islam Negeri Maulana Malik Ibrahim Malang. Disertasi. Pasca Sarjana: Universitas Airlangga- Surabaya.

---------. 2012. Organizational Citizenship Behavior (OCB) dalam Islam. Jurnal Ilmu Ekonomi dan Sosial. Jilid 1. Nomor 2. hlm. 141-148. Malang: Universitas Islam Negeri Maliki Malang.

Organ, D. W. 1988. Organizational Citizenship Behavior: The Good Soldier Syndrome. Lexington, MA: Lexington Books. 
Putri, Putu YudhaAsteria dan Latrini, Made Yenni. 2013. Pengaruh Kepuasan Kerja terhadap Kinerja Karyawan Sektor Publik, dengan In-role Performance dan Innovative Performance sebagai Variabel Mediasi. E-Jurnal Akuntansi Universitas Undayana Fakultas Ekonomi dan Bisnis- Universitas Udayana Bali.

Robbins, Stephen P.. \& Judge, Timothy A.. 2007. Perilaku Organisasi. Buku 1, Cet. 12. Jakarta: Salemba Empat.

Sani, Achmad. \& Maharani, Vivin. 2013. Metode Penelitian Sumber Daya Manusia Teori, Kuesioner, dan Analisis Data. Malang: UIN-Malang Press.

Sloat, K. C. M. 1999. Organizational Citizenship Behavior: Does your firm inspire to be "good citizenship?". Profesional Safeti. Vol.44: 20-23.

Wulandari, Puput. 2015. Pengaruh Kepuasan Kerja Dan Komitmen Organisasi Terhadap Organizational Citizenship Behavior Perawat Rumah Sakit Islam Yogyakarta. Skripsi. Fakultas Ekonomi Universitas Negeri Yogyakarta, Yogyakarta.

Zeithaml, Valerie A. \& Bitner, Mary J. 1996. Services Marketing, McGraw- Hill, New York, N.Y 